\title{
On-site and laboratory soundscape evaluations of three recreational urban spaces
}

Sørensen, Anna Josefine ; Larsen, Thea Mathilde; Bjerre, Lærke Cecilie ; Santurette, Sébastien; Jeong, Cheol-Ho

Published in:

Journal of the Acoustical Society of America

Link to article, DOI:

$10.1121 / 1.4969443$

Publication date:

2016

Document Version

Publisher's PDF, also known as Version of record

Link back to DTU Orbit

Citation $(A P A)$ :

Sørensen, A. J., Larsen, T. M., Bjerre, L. C., Santurette, S., \& Jeong, C-H. (2016). On-site and laboratory soundscape evaluations of three recreational urban spaces. Journal of the Acoustical Society of America, 140. https://doi.org/10.1121/1.4969443

\section{General rights}

Copyright and moral rights for the publications made accessible in the public portal are retained by the authors and/or other copyright owners and it is a condition of accessing publications that users recognise and abide by the legal requirements associated with these rights.

- Users may download and print one copy of any publication from the public portal for the purpose of private study or research.

- You may not further distribute the material or use it for any profit-making activity or commercial gain

- You may freely distribute the URL identifying the publication in the public portal

If you believe that this document breaches copyright please contact us providing details, and we will remove access to the work immediately and investigate your claim 
to the corresponding places. Moreover, the participants could additionally describe the uploaded sounds. This action lasting several months led to a comprehensive database of audio files including related places, descriptions, and ratings. The database was systematically analyzed with respect to several issues, such as general participation level, hot spot identification, and common features of uploaded sounds. The paper will highlight the benefit and limitations of such actions and initiatives applying e-participation with respect to community noise issues and urban planning. [The "Sound of the City" initiative took place within the framework of the Year of Science 2015 and was organized and supported by the Federal Ministry of Education and Research (BMBF).]

2aNS8. Next generation soundscape design using virtual reality technologies. Andy Chung (Smart City Maker, Hong Kong Plaza, Hong Kong HKSAR, Hong Kong, ac@smartcitymaker.com), Wai M. To (Macao Polytechnic Inst., Macao, Macao), and Brigitte Schulte-Fortkamp (TU, Berlin, Germany)

Sound quality has been demanded by the community as part of the smart city initiatives to enjoy a real liveable environment. While a lot of governments pay attention to environmental issues such as air quality and waste, those who care about the sonic environment still rely primarily quantitative levels for either compliance or improvement. Sound quality is most likely ignored. There is at present the international standard ISO 12913-1:2014 providing the definition and the conceptual framework of soundscape. Despite the situation, sound quality is a subjective matter after all and relies very much on human perceptions, as well as the contextual environment. Sound walk, questionnaire, and lab test are common tools used in soundscape studies. These tools allow a good understanding of the perception of the prevailing sonic environment. To figure the sound quality of different design options, though, we can immerse the participants in a virtual, but photorealistic environment, so that they can perceive, compare, and give feedback as if they were in the real environment. A mobile VR application has been developed for iterating soundscape design and fine-tuning. This paper presents this application with case studies.

\section{Contributed Papers}

$10: 45$

2aNS9. On-site and laboratory soundscape evaluations of three recreational urban spaces. Anna Josefine Sørensen (Dept. of Elec. Eng., Tech. Univ. of Denmark, Ørsteds Plads 352, Kgs. Lyngby 2800, Denmark, annajosefine@gmail.com), Thea Mathilde Larsen, Lærke Cecilie Bjerre (Dept. of Civil Eng., Tech. Univ. of Denmark, Kgs. Lyngby, Denmark), Sébastien Santurette (Hearing Systems, Dept. of Elec. Eng., Tech. Univ. of Denmark, Kgs. Lyngby, Denmark), and Cheol-Ho Jeong (Acoust. Technol., Dept. of Elec. Eng., Tech. Univ. of Denmark, Kgs. Lyngby, Denmark)

Soundscape quality was evaluated using four subjective psychological rating factors in three recreational urban spaces in which water and a variation of other natural and anthropogenic sound sources were present. The noise level was measured at each site during occupant peak flows and recordings for listening experiments were made simultaneously. Listeners answered questionnaires either on site or following playback of the recordings in the laboratory, with or without access to each site's visual context. They rated their perception of loudness, acceptance, stressfulness, and comfort, along with their preference toward eight sound sources. The comfort ratings were negatively correlated with loudness and stressfulness and positively correlated with acceptance. The sound level was found to be a good predictor of these subjective parameters in the laboratory, but not on site. Moreover, the availability of the visual context in the listening experiment had no effect on the ratings. The presence of trees and water was also found to increase on-site comfort. Generally, the participants were more positive towards natural sound sources on-site. Overall, the results suggest that on-site context plays an important role for evaluating acoustic comfort in urban recreational areas.

\section{$11: 00$}

2aNS10. Real-time natural soundscape generation based on current weather conditions for workspace voice-masking. Caitlin Riggs and Jonas Braasch (Rensselaer Polytechnic Inst., 110 8th St., Troy, NY 12180, riggs. cait@gmail.com)

Sound masking in work spaces has been implemented to decrease likelihood of distraction from work tasks and improve speech privacy. Current uses of noise as maskers commonly apply broadband white or pink noise signals due to their perceived neutrality. This research combines work into the restorative properties of exposure to nature/natural sounds and pilot studies of natural sounds as maskers to suggest a noise-masking system of "natural" sounds. This system composes a natural soundscape in real time determined by the current weather and time of day such that the masking audio is aesthetically pleasing and informative about the outside world in addition to providing improved speech privacy and reducing distraction when compared to a setting with no masking system. Currently, there is no experimental foundation to suggest that restoration or slowed attentional fatigue can occur if this type of alternative masking sound is presented during a task. This implementation of a dynamic, immersive soundscape masker begins the investigation into the practical efficacy of such a masking system.

\section{1:15}

2aNS11. Evaluation of the noise disturbance and noise limits of a riding horse shooting competition. Juan C. Montoya (Cross Spectrum Acoust., 41 Churchill St., Springfield, MA 01108,jmontoya@csacoustics.com)

Shooting ranges have turned into an unwanted activity in rural communities due to high levels of impulse sound pressure levels. Permanent complaints from neighbors or neighborhood associations pertaining health concerns and noise pollution around areas nearby shooting ranges are a driving force to create state noise control laws. As such, examining zoning will limit (restricting licenses ) to the use of agricultural or residential land to be used for shooting events. Gun noise is measurable and therefore is able to be quantified and characterized. This study evaluates with field noise measurements the events from a "shooting ranch" which currently operates offering a shooting competition while riding a horse emulating the Old West. The analysis of field data pretends to look at metrics such as LAeq (Aweighted equivalent sound level), L90 (noise level exceeded for $90 \%$ of the measurement period), and Lmax ( maximum level if the measurement period from 50 caliber single action revolver gun sounds while shooter is in movement riding a horse. The field measurements were conducted in different nearby residences. The impulse noise lead to examine instead individual gunshots which exceeded background levels by 14 to 34 decibels. Noise levels from Shooting Ranch events are sometimes more than three times the background noise level. Leq and L90 metrics are applicable within individual events.

\section{1:30-12:00 Panel Discussion}

